\title{
Financing Energy Innovation: Internal Finance and the Direction of Technical Change
}

\author{
Joëlle Noailly ${ }^{1,2,3}$ (D) Roger Smeets ${ }^{4}$
}

Accepted: 24 August 2021 / Published online: 21 September 2021

(C) The Author(s) 2021

\begin{abstract}
Achieving the goals of the Paris Agreement and of climate neutrality by 2050 in the European Union will require mobilizing financial investments towards clean energy innovation. This study examines the role of internal finance (cash flows and cash holdings) and financing constraints for innovation in energy technologies. We construct a dataset for 1,300 European firms combining balance-sheet information and patenting activities in renewable (REN) and fossil-fuel (FF) technologies and estimate the sensitivity of patenting activities to firms' internal finance. We use count estimation techniques and control for a large set of firm-specific characteristics and market developments in REN and FF technologies. We find that patenting activities of firms specialized in REN innovation are significantly more sensitive to a shock in cash flows than firms specializing in FF innovation. Hence, our results emphasize that innovative firms in clean energy may be particularly vulnerable to financing constraints. We discuss the implications of these results for energy transition policies aiming to redirect finance towards clean energy R\&D.
\end{abstract}

Keywords R\&D, Patents · Financing constraints $\cdot$ Renewable energy

JEL-Classification: $\mathrm{O} 3 \mathrm{~A} \cdot \mathrm{Q} 4 \cdot \mathrm{G} 3$

\begin{abstract}
This work was initiated by the European Investment Bank (EIB) and we thank Philipp Brutscher (Economic Department, EIB) for providing us with the data. We thank participants at the "Workshop on Corporate Finance Alternatives in Europe", European Investment Bank, Luxembourg, RWI research seminar in Berlin, EAERE Conference in Athens, EEA Conference in Lisbon, WCERE in Gothenburg, and at the First Workshop on Climate Economics, Innovation and Policy at the University of Ottawa for useful comments and suggestions.
\end{abstract}

Joëlle Noailly

joelle.noailly@graduateinstitute.ch

Roger Smeets

rsmeets@business.rutgers.edu

1 Center for International Environmental Studies and Department of International Economics, Graduate Institute of International and Development Studies, Chemin Eugene-Rigot 2, 1211 Geneva, Switzerland

2 VU Amsterdam, De Boelelaan 1105, 1081 HV Amsterdam, The Netherlands

3 Tinbergen Institute, Gustav Mahlerplein 117, 1082 MS Amsterdam, The Netherlands

4 Rutgers University, 1 Washington Park, Newark, NJ 07102, USA 


\section{Introduction}

The ability to achieve sizeable greenhouse gases emissions reductions to address climate change without compromising future economic growth is linked to the deployment and development of clean technologies. The energy sector is key in this respect, as emissions from electricity production are responsible for $40 \%$ of worldwide carbon emissions (IEA 2015). Decarbonizing the energy sector implies shifting away from fossil-fuels, such as coal, oil and gas, which today still account for $70 \%$ of worldwide electricity production and $80 \%$ of global energy investment. Despite recent developments in renewable energy, in particular in wind and solar energy, experts worry that the current pace of innovation efforts in renewable technologies may not be sufficient to achieve the commitment of the Paris Agreement to limit global temperature rise below 2 degrees Celsius (IEA 2017). While technological advances are needed to improve further efficiency and reduce plant-level integration costs of renewables, the share of renewable (REN) energy in global corporate energy R\&D spending remains below 15\% (Frankfurt School-UNEP Centre and BNEF, 2017), and most innovation efforts still tend to be directed to existing incumbent fossil-fuel (FF) technologies. Mobilizing more finance towards clean energy is thus key for the energy transition as recent climate models estimate that the low-carbon energy investment gap to achieve the 2 degrees target of the Paris Agreement represents about one-quarter of annual total energy investment (McCollum et al. 2018). In Europe, the European Commission sees technological innovation and $\mathrm{R} \& \mathrm{D}$ in clean energy as important drivers for achieving the objective of climate neutrality by 2050 (European Commission 2020) and stresses the importance of making finance flows consistent with the low-carbon pathway. According to Polzin and Sanders (2020), Europe still faces a lack of investments to promote R\&D in novel clean energy technologies, such as energy storage, energy-efficiency, decentralized renewable energy, or advanced biofuels and they strongly advocate for a need to "move (some of) the trillions to where they are most needed to facilitate the energy transition in Europe" (Polzin and Sanders 2020, p.2).

Theoretically, several market failures explain why firms tend to underinvest in the development of renewable energy technologies. First, just like other forms of R\&D, firms innovating in REN technologies cannot fully appropriate the returns on their innovation - this is the so-called 'knowledge externality'. Second, in the absence of environmental policy setting a price on carbon emissions, the 'environmental externality' implies that firms have sub-optimal incentives to develop further these low-carbon technologies. Third, pathdependency in innovation, a form of intertemporal knowledge externality, leads technical change to be directed towards FF technologies, where most innovation took place historically (Acemoglu et al. 2012; Aghion et al. 2016; Noailly and Smeets 2015). Finally, an additional market failure that has received less attention in the energy R\&D literature is the prevalence of credit constraints to finance $R \& D$. All R\&D investments are theoretically susceptible to financing constraints due to intrinsic characteristics of the R\&D process (i.e. uncertain outcome of the R\&D process, the lack of collaterals and information asymmetries between investors and innovating firms; Hall and Lerner 2010). An open question, however, is whether financing constraints may be more severe for R\&D in REN than in FF technologies, thereby affecting not only the rate but also the direction of innovation. There are several arguments why financing R\&D may be more difficult for firms innovating in REN (vs. FF) technologies. First and foremost, the technologies present different characteristics substantiating distinct risk-profiles for investors: REN technologies are younger, less mature, and may require higher irreversible sunk costs than their fossil-fuel counterparts. 
In addition, due the presence of the environmental externality, renewable technologies are highly dependent on policy support, which tends to fluctuate over time thereby generating additional risks for investors. Finally, firms undertaking REN innovation may be smaller and younger than other firms and may lack the track record to attract financing.

In this paper, we provide novel empirical evidence on the importance of financing sources - and in particular internal finance in the form of cash flows and cash holdings - for innovation in REN and FF technologies. So far, the literature on energy R\&D has mainly focused on the role of energy prices, market developments and environmental policies (Popp 2002; Johnstone et al. 2010), and more recently on path-dependency in renewable innovation (Noailly and Smeets 2015). By contrast, the role of financial constraints in commanding energy innovation has received little attention in previous research. By studying how the availability of internal finance may differentially affect R\&D investments in renewable and fossil-fuel energy technologies, our study aims to contribute to a new research agenda on the role of financing constraints on the direction of innovation - so far, the evidence has remained mainly anecdotal and in sectors outside energy. ${ }^{1}$ Our study also innovates by explicitly combining the environmental economics literature with the well-developed framework in corporate finance on the role of finance for innovation (Hall and Lerner 2010; Brown et al. 2012). In line with these studies, our econometric approach estimates the R\&D investments' sensitivity to internal financing (e.g. cash flows) for various types of firms. Our analysis relies on an unique dataset combining balance-sheet data with data on firm-level innovation activities (as measured by patents) in renewable and fossil-fuel energy technologies for a sample of 1,300 European firms. Our results suggest that patenting activities of innovating firms specialized in renewable technologies are more sensitive to shocks in cash flows and cash holdings than firms specializing in FF innovation - this result holds over the 1995-2009 period which corresponds to the period of early development of renewable energy technologies. The higher dependence on internal finance for REN firms suggests that these firms may be more vulnerable to financing constraints than FF firms. The significant difference between REN and FF firms remains robust even when looking at specific sub-samples of large and mature firms, which would be expected to be less subject to financing constraints.

Our study is structured as follows. Section 2 reviews previous literature on both corporate finance and environmental economics on the financing of (clean) innovation. Section 3 presents our empirical framework and Sect. 4 describes the data. Section 5 reports our results and Sect. 6 concludes and discusses implications for future energy transition policies aiming to address the investment gap in clean energy R\&D.

\section{Previous Literature}

There is a large body of theoretical and empirical work focusing on the role of financial factors and liquidity for R\&D investment. Firms typically finance their investments by having recourse to both internal (current cash flows and cash holdings) and external finance (debt and stock issues). In the specific case of R\&D investments, several factors explain why access to external finance may be particularly difficult (Hall and Lerner 2010). First,

\footnotetext{
1 Abraham (2011) notes for instance that the pharmaceutical industry has become locked into innovation in drugs which are less complex and provide easier returns than other areas of research, such as diagnostics or life-style remedies.
} 
the majority of $R \& D$ expenditures concerns wages of $R \& D$ workers, rather than capital investment. This implies that banks often cannot claim collaterals in return for R\&D investment. First-time innovators will also often lack a valuable asset that can serve as collateral. As a result, the availability of external (debt) finance is either limited or very costly. Second, due to the highly uncertain nature of the outcome of the innovation process, so is its financial return. The high degree of uncertainty around innovation makes it always difficult to know in advance whether a firm will be successful at innovating or not. As a result, the risk premium charged on external sources of finance is often prohibitively high. Finally, market failures affecting investments also play a role for R\&D investment. There exists asymmetric information between the provider of finance and the innovator, since the latter tends to have more information about potential success or failure. As a result, the highsuccess firms will tend to exit the market as they cannot signal their quality to financiers. Further, moral hazard may induce innovators to spend money on more risky projects than agreed upon ex-ante with the financier. Anticipating such behavior, financiers could limit the availability of external financing, or offer it at higher cost.

Taken together, these problems imply that firms wanting to invest in R\&D activities will typically first deplete their internal cash flows and possibly part of their cash stocks before turning to external sources of financing. A corollary of this result is that firms that are financially constrained will tend to be more sensitive to shocks in the supply of internal finance: for these firms, an expansion of cash flow will be positively associated with more R\&D. These firms will also be more likely to reduce funds from their cash holdings in order to smooth R\&D investment: cash stocks are then used as a 'buffer' to avoid firing R\&D workers during downturns (Brown et al. 2012). The importance of internal finance for R\&D has generated extensive work in the corporate finance literature to test empirically the R\&D-cash flows sensitivity. In reduced form estimation, the theoretical prediction is that an increase in cash flows and a decrease in cash holdings should be associated with an increase in R\&D investment, especially for firms that are financially constrained. Himmelberg and Petersen (1994) find an economically large and statistically significant relationship between R\&D and internal finance in a panel of small firms in high-tech industries, a group of firms particularly likely to face significant internal finance constraints. Mulkay et al. (2001) report a much stronger R\&D-cash flows sensitivity for U.S. firms relative to French firms. Brown and Petersen (2009) find significant effects of cash flows on R\&D investment for young, but not mature firms, in a panel data of 1,347 U.S. publicly traded firms in high-tech industries over the 1990-2004 period. Brown et al. (2012) find similarly a positive link between $R \& D$ and cash flows for a sample of publicly listed companies in Europe, especially in the group of firms most likely to face binding financing constraints (younger, smaller and low-dividend firms). Loof and Nabavi (2016) relate, as we do, cash flows and cash holdings to innovation as measured by patents for a sample of exporting firms in Sweden over the 1997-2007 period. They estimate a positive relationship between cash flows and patenting activities and a negative association between cash holdings growth and innovation for high-tech firms, suggesting that these firms may be particularly financially constrained.

Next to the important role of internal finance, the literature also acknowledges the role of external finance for $\mathrm{R} \& \mathrm{D}$ and in particular equity financing. By contrast to debt financing, equity does not require collateral, and, unlike providers of debt, equity investors share in the upside of the investment. This makes external equity cheaper than external debt. Looking at publicly traded firms, Brown and Petersen (2009), Brown and Petersen (2011) and Brown et al. (2012) all demonstrate the sensitivity of small, young, and technologyintensive firms' R\&D not only to internal finance but also to external equity financing 
constraints. ${ }^{2}$ Taken together, the corporate finance literature sketches a financing hierarchy: first, internal finance is depleted, followed by external equity financing, possibly followed by external debt financing.

So far, there is no evidence in the literature on the cash flows-R\&D sensitivity in the context of energy firms. As energy technologies are highly capital-intensive and require large upfront and often irreversible investments, energy investments exhibit very different risk profiles than investments in other sectors. Within the energy sector, REN and FF technologies also present distinct risk profiles, as investments in renewable energy face specific challenges. First, REN technologies still largely rely on policy support as government intervention is justified in this sector due to the environmental externality. Yet, the risk that policies supporting clean energy are subject to change makes it challenging for investors, who might hold an investment under successive governments. Looking at the determinants of venture capital financing in the renewable energy sector using data on deals in the "clean tech' industry for 26 countries over the period 2005-2010, Criscuolo and Menon (2015) find that national policies designed with a long-term perspective (e.g. feed-in tariffs) are associated with higher investment levels compared to more short-term fiscal policies (e.g. tax incentives, rebates).

Second, REN technologies present higher technological risks than traditional FF ones. Renewables usually require higher upfront capital investments. Nelson and Shrimali (2014) estimate that upfront capital costs represent $84-93 \%$ of total project costs for wind, solar and hydro energy (compared to 66-69\% for coal and $24-37 \%$ for gas). More importantly, technologies that are still in an early stage of development exhibit high failure rates. Ghosh and Nanda (2010) and Nanda and Fleming (2015) discuss how entrepreneurs in renewables need risk capital, not only in early stages, but also later on to demonstrate that the technology can work at scale. This is less of a problem for FF technologies that are wellestablished in the sector. Howell (2017) estimates the impact of being awarded an earlystage research grant by the US Department of Energy on revenues, innovation and survival of small high-tech firms in various sectors related to energy. She finds that firms awarded a grant were more likely to receive subsequent venture capital and to increase their patenting activities and revenues. Her results show evidence of a larger effect for younger firms and for firms in less mature technology areas such as hydropower (wave and tidal), carbon capture and storage, building and lighting efficiency and electric vehicles compared to energy technologies in coal, natural gas, biofuels and recycling technologies, suggesting that immature clean technologies are particularly affected by financing constraints. Our analysis departs from Howell (2017) by focusing on European firms rather than US companies, and by looking at different types of non-public finance. This is important as financial intermediation is not structured in the same way in the US and European markets and policies for REN technologies have been relatively more generous in Europe over the last decades.

Finally, firms active in renewables tend to be relatively small, both in the R\&D and deployment stage (Noailly and Smeets 2015; Donovan 2015). As a consequence, REN projects are often small (compared to nuclear or gas for instance) and small companies do not have an institutional track record to secure debt financing. Incumbents, by contrast, are large companies often specialized in FF technologies and for which shifting to REN often implies cannibalizing their core business. As a result, energy producing firms and utilities

\footnotetext{
2 The established literature in this field mostly focuses on samples of publicly traded firms. In this context, the typical definition of a small firm is one with less than 500 employees, whereas a young firm is one whose IPO took place less than 15 years ago.
} 
are far from active in acquiring promising clean energy startups, thus limiting the available exit options for REN firms (Ghosh and Nanda 2010; Gaddy et al. 2016).

Altogether, these factors explain why REN investments may have an unattractive risk/ return profile compared to FF investments. ${ }^{3}$ Our work contributes to investigate empirically the hypothesis that firms specialized in REN innovation may be more vulnerable to financial constraints than firms specialized in FF innovation.

\section{Empirical Strategy}

We follow the existing literature on financing constraints and innovation (Brown and Petersen 2009; Brown et al. 2012; Loof and Nabavi 2016) and estimate the relationship between innovative activities and firms' level and stock of internal finance. We aim to test whether an expansion of cash flows is positively associated with innovation (suggesting a binding financing constraint) for firms innovating in energy technologies. In particular, we test whether firms innovating in renewable technologies are more susceptible to the innovation-cash flows sensitivity than firms innovating in fossil-fuel technologies. We measure innovation by patent counts and relate patenting activities to firms' financial sources and other controls for firm's and technology markets characteristics. Since we are interested in estimating the differential effect of firms' internal finance on innovation for REN versus FF firms, we pool both samples of firms and introduce interaction terms between cash variables and a dummy for REN firms. More specifically, we estimate the conditional expectation of patenting activities as follows:

$$
\begin{aligned}
E\left(\text { PAT }_{z, i t} / X_{z, i t}, v_{i}, \omega t\right)= & \exp \left(\beta_{1} \text { CashFlows }_{z, i t-1}+\beta_{2} \text { SCashHold }_{z, i t-1}\right. \\
& +\beta_{11} \text { CashFlows }_{z, i t-1} * \text { RENfirms }_{i} \\
& +\beta_{22} \text { CashHold }_{z, i t-1} * \text { RENfirms }_{i} \\
& +\beta_{F} \text { RENfirms }_{i}+\beta_{3} E X T_{z, i t-1} \\
& \left.+\beta_{4} \text { STOCKP }_{z, i t}+\beta_{5} X_{z, i t}+v_{i}+\omega_{t}+\epsilon_{z, i t}\right)
\end{aligned}
$$

where subscripts $z, i$ and $t$ denote technology $(z=R E N, F F)^{4}$, firm and year, respectively; PAT captures (REN or FF) patent counts; CashFlows and $\Delta$ CashHoldings are firm's cash flows and growth in cash holdings respectively; EXT is a vector of financial variables relating to firms' sources of external finance (namely long-term debt $D b t_{z, t-1}$ and stock issues $\left.S t k_{z, t-1}\right) ; S T O C K P$ is the cumulative stock of patents in technology $z$ filed by the firm, reflecting spillovers from past innovation; $X$ is a vector of control variables capturing firm's

\footnotetext{
3 The specificities of the REN sector also explain why project financing is so popular, compared to other sources of financing. Project financing is mainly used for the deployment stage (i.e. construction of REN generating facilities, such as solar or wind turbines) and is less suited for R\&D investment, which is why we abstract from project financing in this paper. This form of financing provides a fixed-income which relies solely on the ability of the project cash flows to repay the amounts borrowed; it typically involves the creation of a project company (Special Purpose Vehicle) which is the legal owner of the project assets and which has contractual agreements with a number of other parties that include off takers, operators, suppliers, insurers and so on. About $30 \%$ of the total new investment deployed into large scale REN projects over the 2003-2013 period was financed by project finance debt.

4 We do not have enough observations to provide a more refined analysis per specific REN - e.g. solar, wind, etc - or FF technology type.
} 
characteristics (firms' ratio of sales to total assets, firm's age and number of employees) and other factors affecting the market for REN and FF technologies (fossil-fuel prices and installed capacity); $v$ and $\omega$ capture unobserved firm, and time heterogeneity, respectively; and $\epsilon$ is an IID error term. All control variables are lagged by one period (except age and number of employees) to allow for some delay in patenting activities.

The theoretical prediction is that financially constrained firms should exhibit a positive coefficient on cash flows - reflecting the positive innovation-cash flow sensitivity - and a negative coefficient on cash holdings growth, as a reduction in cash holdings releases cash for innovation activities (Brown et al. 2012). Hence, a positive coefficient on the total effect of cash flows interacted with REN firms indicates that a positive shock on cash flows is positively associated with innovation of REN firms, and this coefficient is significantly different from the effect on FF firms. Note that in nonlinear count models, interaction effects will not be equal to $\beta_{11}$ and $\beta_{22}$ as in linear models. This is because in nonlinear models the marginal effect is not constant over its entire range. As a result, a simple Wald test will not inform about statistical significance and the signs of the interaction terms do not necessarily indicate the direction of the interaction effect (see Appendix). ${ }^{5}$ To calculate total interaction effects, we follow Ai and Norton (2003) and apply the Delta method for variance estimation to compute standard errors for the interaction terms.

While equation (1) allows us to estimate our hypothesis of significant difference across REN and FF firms, we also estimate separate estimations on each specific subsample of firms as this allows us to better illustrate the specific effects of our control variables on each type of firms:

$$
\begin{aligned}
E\left(\text { PAT }_{z, i t} / X_{z, i t}, v_{i}, \omega_{t}\right)= & \exp \left(\beta_{z, 1} \text { CashFlows }_{z, i t-1}+\beta_{z, 2} \text { ACashHoldings }_{z, i t-1}+\beta_{z, 3} \text { EXT }_{z, i t-1}\right. \\
& +\beta_{z, 4} \text { STOCKP }_{z, i t}+\beta_{z, 5} X_{z, i t}+v_{i} \\
& \left.+\omega_{t}+\epsilon_{z, i t}\right)
\end{aligned}
$$

We estimate equations (1) and (2) by negative binomial models, which do not impose equidispersion (i.e. the equivalence of the conditional mean and variance). ${ }^{6}$ Estimating the relationship between financial sources and patenting potentially suffers from a number of econometric challenges. First, there may be omitted variables at the firm-level which could be correlated with both cash flows and patenting. Cash-rich firms may for instance be more likely to patent as this is a costly process. Some firms, e.g. with better managerial abilities, may be both more able to attract funding and to patent than others. All these factors could imply that financial variables are correlated with the error term of the regression and yield inconsistent estimates. We address this issue first by introducing firms' fixed effects $v_{i}$ into the count data model. Since equations (1) and (2) are dynamic models in which innovation is determined by past realisations of patenting activities due to the inclusion of the cumulative patent stock on the right-hand-side, the assumption of strict exogeneity is violated and we cannot rely on the conditional fixed-effect Poisson estimator as in Hausman et al. (1984). Instead, we introduce firms' fixed effects $v_{i}$ using the 'presample estimator' introduced by Blundell et al. (2002), which is used as an initial condition to proxy for unobserved heterogeneity. More specifically, we compute the firm's cumulative patent stock in all technologies (i.e. not only REN and FF) over the presample period (1978-1994)

\footnotetext{
5 A significant interaction effect is possible even when $\beta_{11}=0$.

6 In robustness analysis, we will also consider the Poisson model.
} 
and introduce it as $v_{i}$ in equation (1) in order to capture individual firms' propensity to patent (Blundell et al. 2002; Aghion et al. 2016; Noailly and Smeets 2015). To control for additional time-varying firms' heterogeneity, we include controls for firms' characteristics, namely firm's age, sales and number of employees. These variables control for instance for the fact that as firms grow older and larger they may both increase their levels of internal finance and become more successful at patenting. In addition, these variables control for investment opportunities as the level of cash flows may also reflect the value of future growth opportunities, such as a greater demand for the firms' product (Alti 2003; Erickson and Whited 2000). Finally, we include a full set of time dummies $\omega_{t}$ to control for timedependent factors common to all firms, such as business cycles, which affect both financing and innovation.

Second, we may be concerned by the fact that cash variables may be potentially endogenous to innovation activities due to reverse causality. Previous literature shows for instance that startups use patents as a signal to investors (Conti et al. 2013). In our case, this is likely less of an issue since our sample is composed of established firms, rather than startups. Yet, to address this potential source of endogeneity, we use a control function approach to instrument internal finance. As finding an exogenous instrument for financing sources (i.e. correlated with firm's finance but not with innovation) is notoriously difficult, we follow the corporate finance literature and use lagged financial variables dated over $t-3$ and $t-4$ as instrumental variables (Brown et al. 2012). ${ }^{7}$

For non-linear count models such as Poisson and negative binomial, the control function estimation is more efficient and consistent than the standard instrumental variables model, since the two-stage interpretation of linear two-stage least squares does not carry over to non-linear models (Cameron and Trivedi 2013; Wooldridge 2015). The control function approach operates by estimating $\mathrm{CF}_{t-1}$ - our potentially endogenous variable of interest-as a function of our instrument and other exogenous variables, and then inserting the predicted errors from this first stage into the second stage as a separate control variable. A simple test of the statistical significance of the coefficient on the predicted residuals will inform us whether our $\mathrm{CF}_{t-1}$ is indeed endogenous, a procedure equivalent to a DurbinHu-Hausman exogeneity test (Wooldridge 2015). Another major advantage of the control function approach is that it makes it much easier to handle interaction terms that involve endogenous regressors. In our case, if we want to control for the endogeneity of both $\mathrm{CF}_{t-1}$ and the interaction term $\left(\mathrm{CF}_{t-1}\right.$ * REN firms), it is sufficient to only estimate the first-stage regression and add the fitted residuals in the second stage equation (Wooldridge, 2015, p. 428; Papies et al. 2017). Finally, the control function approach requires bootstrapping of standard errors.

\section{Data}

\subsection{Measuring Innovation}

We measure innovation in REN and FF technologies using patent data, following the literature on low-carbon innovation (Popp 2002; Johnstone et al. 2010). There are several

\footnotetext{
7 Due to the limited degrees of freedom, we cannot perform any nonlinear instrumental variable estimation via GMM.
} 
advantages and limitations to working with patent data, which have been discussed at length in the literature. ${ }^{8}$ We extract patents from the Orbis dataset provided by Bureau van Dijk and linked to the European Patent Office's (EPO) PATSTAT dataset. ${ }^{9}$ The main advantage of using the Orbis-PATSTAT dataset to extract relevant patents is that it provides us with an unique firm's identifier that allows us to match firm-level patents to firms' balance sheet and income statement data.

We extract data on firms' patenting activities in REN and FF technologies using International Patent Classification (IPC) codes to select patents in REN and FF technologies. REN patents include patents in wind, solar, hydro, marine, biomass, geothermal and waste energy technologies (Johnstone et al. 2010), while FF patents include patents related to production of fuel gases by carbureting air, steam engine plants, gas turbine plants, hotgas or combustion-product positive displacement engine, steam generation, combustion apparatus, furnaces and improved compressed-ignition engines (Lanzi et al. 2011). We also extract firms' patents in all technologies (not only REN or FF) to be able to correct for firms' propensity to patent.

Just as in Noailly and Smeets (2015), we focus on firms that have been granted at least one REN or FF patent at the EPO and 17 national patent offices (EU-15, Switzerland and Norway). We count the number of granted patents per firm per year over the 1995-2009 period $^{10}$, including only first priority patents and excluding equivalent patent filings. ${ }^{11}$ The fact that we focus on granted patents of firms registered in Orbis implies that our sample is not likely to include the lowest quality patents. ${ }^{12}$ We use the application year of priority patents, as this is closer to the year of the inventive idea than the year in which the patent was granted. We compute the annual count of REN and FF patents per firm as well as firmspecific REN and FF knowledge stocks, which are the cumulated number of patent counts over the period. ${ }^{13}$

\subsection{Sources of Finance}

Using the financial database of Orbis, we have access to data on firms' (consolidated) balance sheets and income statements. We conduct a series of consistency checks as in Kalemli-Ozcan et al. (2015) recommended when working with financial variables in Orbis (see Appendix) and we trim the $1 \%$ tails of all regression variables to remove outliers. We

\footnotetext{
8 A main caveat of working with patents is that not all inventions are patented, as for strategic reasons firms may prefer not to disclose valuable information. The value of patents is also very heterogeneous: only a few patents will lead to successful commercial applications. Despite these limitations, the link between patents and inventions has been clearly established in the literature (Griliches 1990) as patents are correlated with other indicators of innovative activity, such as R\&D expenditures or new product introductions. For our purpose, the main advantage of patent data is that they are highly disaggregated and are available at the firm and technology level.

9 We thank the European Investment Bank for providing us with the dataset.

10 Note that our data range stops in 2009 before the financial crisis. In this way, we avoid the complexity of studying the financing of energy technologies in the aftermath of the crisis, characterized by specific Green New Deal policies difficult to account for. Such analysis would deserve a study on its own in future work.

11 For patent families with multiple priorities, we only keep the patent with the earliest priority date.

12 In addition, we restrict our analysis to firms that could be linked to the Orbis dataset, therefore excluding patents from individuals, which may be of lower value.

13 Knowledge stocks are calculated using the perpetual inventory method, assuming an annual depreciation rate of $15 \%$.
} 
are left with a sample of 1300 firms over the 1995-2009 period for which we can exploit balance sheets data. We consider the following indicators of financing sources:

- Cash flows: computed as total cash flows (including depreciation), divided by the endof-last-period stock of total assets.

- Cash holdings growth: change in firm-level stocks of cash (cash holdings and cash equivalents, divided by the end-of-last-period stock of total assets). This variable aims to capture so-called 'R\&D smoothing' (Brown and Petersen 2011).

- Long-term debt: computed as the annual change in total long-term debt, divided by the end-of-last-period stock of total assets.

- Stock issues: computed as the annual change in outstanding issued share capital, divided by the end-of-last-period stock of total assets.

All variables are measured in 100,000 USD, using the exchange rate data from the International Energy Agency to convert the financial variables into US dollars.

\subsection{Other Firm-level Variables}

We further extract a number of firm-level control variables from the financial database of Orbis and include (net) sales ${ }^{14}$, the number of employees and the age of the firm.

In addition, we add variables that aim to capture changes in the macro-economic environment of the firm in particular with respect to the market and policy environment affecting REN and FF technologies in Europe over the last decades. These variables are included as additional controls in our regressions. ${ }^{15}$ Table 6 in the Appendix provides specific definitions of all these variables and their data sources.

Energy prices: we extract data from the Energy Prices and Taxes database of the International Energy Agency on country-level prices of the different fossil-fuel energy sources, namely: oil, gas and coal. ${ }^{16}$ To make FF prices firm-specific, we weight FF prices according to the firm's distribution of patent filings across countries using information on patent families as in Noailly and Smeets (2015) and Aghion et al. (2016). Since energy prices include taxes, this variable can proxy for carbon pricing policies.

Market size: we extract data from the Energy Statistics database from the IEA on electricity output from REN and FF sources per country in total number of gigawatt hours generated by power plants. For FF energy, we use data on electricity output in oil, gas and coal, while for REN energy we have access to disaggregated data on electricity output from solar, wind, hydro, marine, geothermal, biomass and waste energy. Market size variables also capture demand-pull policies, such as feed-in tariffs, put in place in specific countries. We compute firm-specific market size by using designation country weights as well as technology weights in each firm's patent portfolio (see Appendix). Market size variables are likely to capture demand-pull policies (e.g. guaranteed tariffs, investment and production tax credits) that aim to increase the market for renewables.

\footnotetext{
14 Sales are computed as the ratio of net sales to end-of-last period total assets.

15 As our focus is on interpreting the impact of financial variables, we refer to Noailly and Smeets (2015) for a more extensive discussion of how these other control variables affect REN and FF innovation.

16 These are prices paid at the power plant for electricity generation, i.e. prices paid by electricity facilities for a certain type of fuel (including taxes).
} 


\subsection{Descriptive Statistics}

We extract patents from two types of firms: (1) firms that specialize solely in REN innovation (REN firms), (2) firms that specialize solely in FF innovation (FF firms) over the 1995-2009 period. ${ }^{17}$ This provides a sample of 1,287 firms with a majority of FF firms (68\%). Including all controls, our sample of firms reduces to 1,203 firms composed of 390 REN firms and 813 FF firms. Our sample of patents consists of 1,606 patents, among which about one third are from firms innovating in REN technologies. Figure 1 plots the evolution of FF and REN patents over the period 1995-2009.

Table 1 presents the summary statistics of financial variables for the different types of firms. For firms specialized in REN innovation, firm's median flows of cash, cash holdings, flows of total debt and new stock issues, all scaled by beginning-of-period total assets, are of 0.093, 0.050, 0 and 0.001, respectively. For all firms, median cash flows and cash holdings ratios are always much larger than other financing sources, underlying the critical role of internal finance in our sample of innovative firms. This is not surprising given evidence from previous literature ${ }^{18}$ and given that we do not consider publicly listed firms. ${ }^{19}$ Median values of debt and stock issues are always close to zero, so a typical firm in our sample obtains very little external finance. Regarding other firms' characteristics, we can see in Table 1 that on average REN firms tend to be about 5-6 years younger, have a smaller number of employees than FF firms, and file slightly less patents (all technologies included) per year.

\section{Results}

In Table 2, we present the baseline results of estimating equation (1) by negative binomial models for the pooled sample of REN and FF firms. The dependent variable in every column is the number of patents (either REN or FF) per firm $i$ and year $t$. Column (1) includes only internal finance variables and firms' characteristics, column (2) adds the full set of technology market controls and column (3) adds external finance variables. Our preferred specification is provided in column (3) with all controls. All models include full sets of year dummies and firms' fixed effects captured by the presample patent stock. In all regressions, the presample variable capturing firms' fixed effects and heterogeneity has a significant negative coefficient. Note that we do not have a priori expectations on the sign of this coefficient, but the fact that we do find statistically significant coefficients in

\footnotetext{
17 We exclude 'mixed' firms that are active in both technological fields, REN and FF, from the analysis. These very large firms (mostly active in FF technologies) differ considerably from our set of specialized firms and their financing sources and structure cannot be compared with the ones of small specialized firms. Table 7 in Appendix shows that these firms are on average 5 times larger in terms of number of employees and total assets and patent 10 times more than specialized firms. See also Noailly and Smeets (2015) for a more in-depth discussion of the difference between mixed and specialized firms. Although mixed firms would certainly deserve an analysis on their own, the sample size - 90 mixed firms over the 1995-2009 - is too limited to provide reliable estimates.

18 Brown et al (2009) find that young firms have average cash holdings ratios that are twice as large as the cash holdings for mature firms, reflecting the fact that buffer stocks of liquidity are more important for firms more likely to face financial constraints.

19 Mean debt and stock issues to assets ratios for specialized REN and FF firms are 10 to $20 \%$ of mean cash ratios, and this is mainly explained by outlier firms as the median debt and stock issues ratios remain very low.
} 
most models suggests that the presample variable does capture part of the unobserved firm heterogeneity.

As discussed in Sect. 3, we look at how internal finance relates to patenting activities for REN and FF firms by including interaction terms between cash flows and cash holdings growth and a dummy for specialized REN firms, respectively. In this way, we can compare the coefficients of internal finance variables across both types of firms to determine whether the effect on REN firms is significantly different from the effect on FF firms. Since we conduct nonlinear estimation, we cannot directly interpret the coefficient - nor the sign - of the interacted variables. Instead, we compute total interaction effects using the Delta method (Ai and Norton 2003) and report them at the bottom of Table 2 (see Appendix for computation details). Across all specifications in columns (1) to (3), we find that the interaction term $\left(\mathrm{CF}_{t-1} *\right.$ REN firms) is significant and positive, while the interaction term ( $\Delta$ Cashholdings $_{t-1} \times$ REN firms) is never significant. The positive association between cash flows and innovation for REN firms provides support to the hypothesis that the innovation-cash flows sensitivity is significantly higher for REN firms than for FF firms, suggesting that REN firms are more financially constrained than FF firms. The total interaction effect on $\left(\mathrm{CF}_{t-1} * \mathrm{REN}\right.$ firms) increases in column (3) when we include controls for all potential other sources of finance, namely external financing via long-term debt and stock issues. The fact that we never find a statistically significant coefficient for the interaction term with cash holding growth suggests that there is no significant difference between REN and FF firms in terms of R\&D smoothing. Regarding external sources of finance, we find no evidence in column (3) for a significant association between long-term debt and stock issues and patenting activities, respectively. This is not very surprising given that we showed in Sect. 4 that firms in our sample receive very little external finance.

In column (4) of Table 2, we report the results of our instrumental variable estimation using a control function approach. We follow Brown et al. (2012) and instrument $\mathrm{CF}_{t-1}$ by using lagged cash flows averaged over $t-3$ to $t-4$, although results are robust to using lags over $t-2$ and $t-3$ as shown in column (5). ${ }^{20}$ For cash holdings growth, however, lagged values never appear to be correlated with $\Delta$ Cashholdings $_{t-1}$ in first stage estimations (see columns (3) to (4) in Table 5 in Appendix). Since we cannot find any suitable instrument for cash holdings growth, we focus on instrumenting $\mathrm{CF}_{t-1}$, as this is also the only variable for which we find evidence of a significant association with innovation in columns (1)-(3) of Table 2.

In the bottom panel of column (4), we see that the estimated interacted coefficient between cash flows and REN firms remains positive and statistically significant. The fact that the first stage residuals are not significant in column (4) indicates that we cannot reject the null hypothesis of exogeneity and thereby provides reassurance that our estimation results in column (3) are not being influenced by endogeneity (Wooldridge, 2015; Cameron and Trivedi, 2013, Chapter 10). Likely, our large set of firms' controls and fixed effects already captures much of firms' heterogeneity. ${ }^{21}$ Column (5) shows that the results are robust to using lagged cash flows averaged over $t-2$ to $t-3$ as an instrument for $\mathrm{CF}_{t-1}$. Again, first-stage residuals are not significant and we cannot reject exogeneity.

Looking at other control variables in Table 2, we find that firm's age is significantly negatively associated with patenting activities, while firm's size in terms of number of employees is positively associated with innovation. By contrast, we find no significant

${ }^{20}$ Using further lags (t-5 and t-6) would significantly affect our number of observations.

21 Table 5 in Appendix reports the full first stage results. 


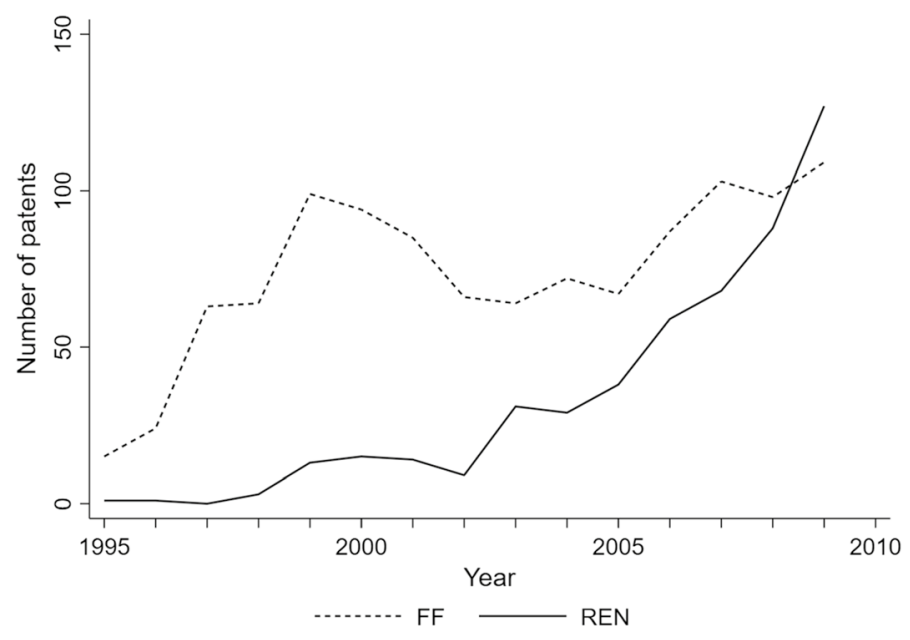

Fig. 1 Number of REN and FF patents, 1995-2009

association between the sales ratio and patenting activities. There is evidence for pathdependency in innovation at the firm level, as a larger stock of past REN and FF patents respectively is positively associated with higher patenting activities. Fossil fuel prices tend on average to be negatively associated with patenting activities of all firms. The market size of REN technologies is positively associated with firm-level innovation, but there is no significant association between FF market size and firm-level patents.

In Table 3, we estimate equation (2) for each separate group of firms to better identify separate effects on REN and FF firms. The significant coefficients on internal finance variables for the subset of REN firms confirm previously found results: there is evidence of a positive association between cash flows and patenting activities for REN firms. Changes in cash holdings are negatively associated with patenting activities for REN firms in columns (1)-(3), although the coefficient is only statistically significant in column (3) when we include the full set of controls. Looking at columns (4)-(6) in specifications for the sample of firms that specialize in FF innovation, we find no evidence of a positive association between cash flows or changes in cash holdings and patenting activities. The coefficient for cash holdings is only negative in column (6) when we include the full set of controls, although insignificant. Here, the negative association between cash holdings growth and patenting activities in column (3) suggests that REN firms may be using cash stocks as a buffer to smooth R\&D over time. However, we saw in Table 2 that the coefficient on cash holdings growth is not significantly different from the coefficient for FF firms. As before, external finance (long-term debt and stock issues) does not appear to be associated with patenting activities of specialized firms in columns (3) and (6). The only exception is a negative association between long-term debt and patents for FF firms in column (6). A possible interpretation for this result is that other investments - such as physical capital investments - financed by long-term debt may crowd out innovation investments for these firms, but these results should be taken with caution given the low level of external finance 
Table 1 Summary Statistics

\begin{tabular}{|c|c|c|c|c|c|c|}
\hline & \multicolumn{6}{|c|}{ REN firms } \\
\hline & Mean & SD & 50th perc. & 75th perc. & Min & Max \\
\hline $\mathrm{CF}_{t-1}$ & $0.121^{a}$ & 0.236 & 0.093 & 0.152 & -0.931 & 6.908 \\
\hline CashHolding $_{t-1}$ & $0.131^{a}$ & 0.388 & 0.050 & 0.153 & 0.000 & 14.9 \\
\hline $\mathrm{Dbt}_{t-1}$ & 0.025 & 0.330 & 0.000 & 0.026 & -0.981 & 12.167 \\
\hline $\mathrm{Stk}_{t-1}$ & 0.018 & 0.078 & 0.001 & 0.009 & 0.000 & 1.686 \\
\hline Sales $_{t}$ & $1.679^{a}$ & 1.784 & 1.327 & 2.015 & 0.000 & 42.464 \\
\hline Total Assets ${ }_{t}$ & $5,474^{a}$ & 24,042 & 362 & 1,676 & 11.2 & 389,237 \\
\hline Age $_{t}$ & $31^{a}$ & 32 & 21 & 37 & 0 & 191 \\
\hline Employees $_{t}$ & $1,979^{a}$ & 11,606 & 165 & 610 & 0 & 319,998 \\
\hline $\mathrm{REN}_{\text {patents }}$ & 0.249 & 1.105 & 0 & 0 & 0 & 19 \\
\hline \multirow[t]{3}{*}{ All patents ${ }_{t}$} & $3.858^{a}$ & 15.013 & 0 & 1.5 & 0 & 197.5 \\
\hline & \multicolumn{6}{|c|}{ FF firms } \\
\hline & Mean & SD & 50th perc. & 75th perc. & Min & Max \\
\hline $\mathrm{CF}_{t-1}$ & 0.098 & 0.176 & 0.083 & 0.134 & -1.245 & 8.780 \\
\hline CashHolding $_{t-1}$ & 0.105 & 0.184 & 0.043 & 0.128 & 0.000 & 4.45 \\
\hline $\mathrm{Dbt}_{t-1}$ & 0.012 & 0.350 & 0.000 & 0.010 & -0.866 & 22.610 \\
\hline Stk $_{t-1}$ & 0.014 & 0.180 & 0.001 & 0.007 & 0.000 & 11.759 \\
\hline Sales $_{t}$ & 1.444 & 1.016 & 1.296 & 1.808 & 0.000 & 27.327 \\
\hline Total Assets ${ }_{t}$ & 8677 & 27,565 & 579 & 3471 & 11.1 & 376,038 \\
\hline Age $_{t}$ & 37 & 37 & 26 & 48 & 0 & 432 \\
\hline Employees $_{t}$ & 2978 & 9842 & 263 & 1,278 & 0 & 115,000 \\
\hline FF patents ${ }_{t}$ & 0.231 & 0.802 & 0 & 0 & 0 & 18 \\
\hline All patents ${ }_{t}$ & 5.628 & 34.885 & 0 & 2 & 0 & 1028 \\
\hline
\end{tabular}

Average over firm-year observations, 1995-2009: Number of observations: REN firms N=1,995 firm x year, FF firms $\mathrm{N}=4,811$ firm $x$ year ${ }^{a}$ indicates significant difference (below 5\%) with FF firms. All balance sheets variables(except age and number of employees) are scaled by end-of-last-period total assets

in our sample of firms. Finally, the results in Table 3 show that REN market size - a proxy for REN market subsidies over the period - is positively associated with patenting activities on REN firms as expected. Fossil fuel prices - capturing energy taxation - are negatively associated with patenting activities by FF firms. ${ }^{22}$

In Table 4, we add further robustness tests to estimating equation (1). In columns (1) and (2), we consider the specific subsamples of mature and large firms as we may be worried that in Table 2 the differential impact of internal finance on innovation may be driven by the fact that FF firms are different from REN firms in terms of age and size as established in Table 1. Hence, in column (1) of Table 4, we consider the subsample of mature

\footnotetext{
22 Note that we do not have a priori expectations on the coefficient for FF prices, as higher FF prices might encourage firms to innovate more in FF technologies (to develop more efficient and cheaper technologies) but could also encourage firms to develop alternative technologies such as REN technologies and thereby discourage FF innovation.
} 
Table 2 Pooled estimations with interaction terms

\begin{tabular}{|c|c|c|c|c|c|}
\hline Specialized firms & (1) & (2) & (3) & $\begin{array}{l}(4) \\
\text { Control } \\
\text { Function } \\
(t-3, t-4)\end{array}$ & $\begin{array}{l}(5) \\
\text { Control } \\
\text { Function } \\
(t-2, t-3)\end{array}$ \\
\hline $\mathrm{CF}_{t-1}$ & $\begin{array}{l}0.089 \\
(0.165)\end{array}$ & $\begin{array}{l}0.090 \\
(0.163)\end{array}$ & $\begin{array}{l}-0.018 \\
(0.179)\end{array}$ & $\begin{array}{l}0.566 \\
(0.702)\end{array}$ & $\begin{array}{l}0.048 \\
(0.567)\end{array}$ \\
\hline $\mathrm{CF}_{t-1} \times \mathrm{REN}$ firms & $\begin{array}{l}0.779 * \\
(0.413)\end{array}$ & $\begin{array}{l}0.759 * \\
(0.426)\end{array}$ & $\begin{array}{l}0.979 * * \\
(0.453)\end{array}$ & $\begin{array}{l}0.971 * \\
(0.583)\end{array}$ & $\begin{array}{l}1.239 * * * \\
(0.438)\end{array}$ \\
\hline$\Delta$ Cashholdings $_{t-1}$ & $\begin{array}{l}-0.118 \\
(0.252)\end{array}$ & $\begin{array}{l}-0.073 \\
(0.257)\end{array}$ & $\begin{array}{l}-0.136 \\
(0.268)\end{array}$ & $\begin{array}{l}-0.417 \\
(0.359)\end{array}$ & $\begin{array}{l}-0.232 \\
(0.317)\end{array}$ \\
\hline$\Delta$ Cashholdings $_{t-1} \times$ REN firms & $\begin{array}{l}-0.145 \\
(0.319)\end{array}$ & $\begin{array}{l}-0.162 \\
(0.322)\end{array}$ & $\begin{array}{l}-0.235 \\
(0.306)\end{array}$ & $\begin{array}{l}0.008 \\
(0.557)\end{array}$ & $\begin{array}{l}-0.112 \\
(0.454)\end{array}$ \\
\hline RENfirms & $\begin{array}{l}0.203 * * \\
(0.096)\end{array}$ & $\begin{array}{l}0.499 * * * \\
(0.137)\end{array}$ & $\begin{array}{l}0.520 * * * \\
(0.144)\end{array}$ & $\begin{array}{l}0.436 * * * \\
(0.149)\end{array}$ & $\begin{array}{l}0.494 * * * \\
(0.140)\end{array}$ \\
\hline $\mathrm{Dbt}_{t-1}$ & & & $\begin{array}{l}-0.325 \\
(0.204)\end{array}$ & $\begin{array}{l}-0.527 * \\
(0.281)\end{array}$ & $\begin{array}{l}-0.434 * \\
(0.242)\end{array}$ \\
\hline Stk $_{t-1}$ & & & $\begin{array}{l}-0.183 \\
(0.547)\end{array}$ & $\begin{array}{l}-1.005 \\
(1.483)\end{array}$ & $\begin{array}{l}-0.913 \\
(1.009)\end{array}$ \\
\hline $\log (\text { Age })_{t}$ & $\begin{array}{l}-0.217 * * * \\
(0.049)\end{array}$ & $\begin{array}{l}-0.207 * * * \\
(0.046)\end{array}$ & $\begin{array}{l}-0.192 * * * \\
(0.048)\end{array}$ & $\begin{array}{l}-0.200 * * * \\
(0.058)\end{array}$ & $\begin{array}{l}-0.196 * * * \\
(0.048)\end{array}$ \\
\hline $\log (\text { Employees })_{t}$ & $\begin{array}{l}0.092 * * * \\
(0.017)\end{array}$ & $\begin{array}{l}0.081 * * * \\
(0.018)\end{array}$ & $\begin{array}{l}0.089 * * * \\
(0.019)\end{array}$ & $\begin{array}{l}0.080 * * * \\
(0.021)\end{array}$ & $\begin{array}{l}0.090 * * * \\
(0.018)\end{array}$ \\
\hline Sales $_{t-1}$ & $\begin{array}{l}0.039 \\
(0.030)\end{array}$ & $\begin{array}{l}0.027 \\
(0.030)\end{array}$ & $\begin{array}{l}0.038 \\
(0.033)\end{array}$ & $\begin{array}{l}0.035 \\
(0.040)\end{array}$ & $\begin{array}{l}0.033 \\
(0.037)\end{array}$ \\
\hline $\log (\mathrm{STOCKP})_{t-1}$ & $\begin{array}{l}0.866 * * * \\
(0.064)\end{array}$ & $\begin{array}{l}0.849 * * * \\
(0.062)\end{array}$ & $\begin{array}{l}0.868 * * * \\
(0.062)\end{array}$ & $\begin{array}{l}0.853 * * * \\
(0.081)\end{array}$ & $\begin{array}{l}0.867 * * * \\
(0.073)\end{array}$ \\
\hline $\log (\mathrm{FF} \text { prices })_{t-1}$ & & $\begin{array}{l}-1.356 * * * \\
(0.512)\end{array}$ & $\begin{array}{l}-1.390 * * * \\
(0.539)\end{array}$ & $\begin{array}{l}-1.328 * * \\
(0.654)\end{array}$ & $\begin{array}{l}-1.303 * * \\
(0.560)\end{array}$ \\
\hline $\log (\text { REN market size })_{t-1}$ & & $\begin{array}{l}0.388 * * * \\
(0.126)\end{array}$ & $\begin{array}{l}0.437 * * * \\
(0.133)\end{array}$ & $\begin{array}{l}0.374 * * \\
(0.152)\end{array}$ & $\begin{array}{l}0.452 * * * \\
(0.144)\end{array}$ \\
\hline $\log (\text { FF market size })_{t-1}$ & & $\begin{array}{l}-0.061 \\
(0.240)\end{array}$ & $\begin{array}{l}-0.106 \\
(0.234)\end{array}$ & $\begin{array}{l}0.163 \\
(0.293)\end{array}$ & $\begin{array}{l}-0.113 \\
(0.262)\end{array}$ \\
\hline presample & $\begin{array}{l}-0.169 * * * \\
(0.040)\end{array}$ & $\begin{array}{l}-0.132 * * \\
(0.058)\end{array}$ & $\begin{array}{l}-0.128 * * \\
(0.059)\end{array}$ & $\begin{array}{l}-0.182 \\
(0.120)\end{array}$ & $\begin{array}{l}-0.125 \\
(0.099)\end{array}$ \\
\hline Constant & $\begin{array}{l}-1.919 * * * \\
(0.383)\end{array}$ & $\begin{array}{l}-0.381 \\
(1.041)\end{array}$ & $\begin{array}{l}-0.444 \\
(1.075)\end{array}$ & $\begin{array}{l}-0.713 \\
(1.299)\end{array}$ & $\begin{array}{l}-0.582 \\
(1.225)\end{array}$ \\
\hline First-stage residuals & & & & $\begin{array}{l}-0.587 \\
(0.687)\end{array}$ & $\begin{array}{l}-0.018 \\
(0.656)\end{array}$ \\
\hline \multicolumn{6}{|l|}{$\begin{array}{l}\text { Total interaction terms (Delta } \\
\text { Method) }\end{array}$} \\
\hline $\mathrm{CF}_{\mathrm{t}-1} * \mathrm{REN}$ firms & $\begin{array}{l}0.266 * * \\
(-0.162)\end{array}$ & $\begin{array}{l}0.283 * * \\
(0.174)\end{array}$ & $\begin{array}{l}0.550 * * \\
(0.350)\end{array}$ & $\begin{array}{l}0.336 * * * \\
(0.098)\end{array}$ & $\begin{array}{l}0.340 * * * \\
(0.108)\end{array}$ \\
\hline CashHoldings $_{\mathrm{t}-1} * \mathrm{REN}$ firms & $\begin{array}{l}-0.041 \\
(0.069)\end{array}$ & $\begin{array}{l}-0.053 \\
(0.066)\end{array}$ & $\begin{array}{l}-0.091 \\
(0.067)\end{array}$ & $\begin{array}{l}-0.040 \\
(0.122)\end{array}$ & $\begin{array}{l}-0.053 \\
(0.093)\end{array}$ \\
\hline Observations & 7,412 & 7,199 & 6,806 & 5,866 & 6,726 \\
\hline
\end{tabular}


Table 2 (continued)

\begin{tabular}{llllll}
\hline Specialized firms & $(1)$ & $(2)$ & $(3)$ & $(4)$ & (5) \\
& & & Control & Control \\
& & & Function & Function \\
& & & & $(t-3, t-4)$ & $(t-2, t-3)$ \\
\hline Log Likelihood & -3802 & -3714 & -3491 & -2941 & -3422 \\
Number of firms & 1287 & 1260 & 1203 & 1083 & 1179 \\
\hline
\end{tabular}

$* p<0.1, * * p<0.05, * * * p<0.01$. The dependent variable in every column is the number of patents per firm $i$ and year $t$. Robust standard errors are clustered at the firm level. In columns (4) and (5), the models are estimated using the control function approach with bootstrap standard errors with 150 iterations. First-stage estimations are provided in Table 5, columns (1) and (2) respectively. All specifications include year fixed effects. Fossil fuel price and market size variables are constructed by using firm-specific weights reflecting the firms' patent portfolio and designation countries as in Noailly and Smeets (2015)

REN and FF firms (with at least 25 years of existence) and in column (2), we consider the subsample of large REN and FF firms (with more than the median of 200 employees). We find that the significant difference on the innovation-cash flows sensitivity still holds for the subsamples of mature and larger specialized firms, respectively. Indeed, the total interaction effect of $\left(\mathrm{CF}_{t-1} * \mathrm{REN}\right.$ firms) is significant and positive. This is striking as this suggests that innovation activities of mature and large REN firms are significantly more sensitive to a shock in internal finance - and thus more susceptible to financing constraints - than similar mature and larger FF firms. This result tends to suggest that financing constraints are not a manifestation of the smaller size or lower maturity of REN companies, but more likely of other factors such as distinct technological and policy risks. Finally, in column (3), we find that our results are robust to a Poisson estimation model. In this case, the total interaction effect of $\left(\mathrm{CF}_{t-1} * \mathrm{REN}\right.$ firms $)$ remains significant and positive, albeit smaller.

\section{Conclusions}

This paper aimed to examine the role of firms' internal finance as a source of financing for energy innovation. Drawing on the result from the corporate finance literature that firms that are financially constrained tend to be more sensitive to shocks in the supply of internal finance, we investigated whether firms specializing in REN innovation exhibit a higher innovation-cash flows sensitivity - an indication of binding financial constraints - than firms specializing in FF innovation. Compared to FF innovation, REN innovation presents more risks for investors, due to the larger reliance on (uncertain) policy support and specific technological characteristics. Our study provides thus some first empirical support for the hypothesis that clean energy innovation may be particularly more difficult to finance than fossil-fuel based innovation, confirming qualitative evidence from the literature. Using count estimation techniques for a sample of European firms over the 1995-2009 period - a period of early development of REN technologies supported by market subsidies - we find that an extension of cash flows is positively associated with more patenting activities by REN firms and that this effect is significantly different for REN firms compared to FF firms, suggesting that firms specialized in REN technologies 
Table 3 Estimations on REN and FF firms subsamples

\begin{tabular}{|c|c|c|c|c|c|c|}
\hline & (1) & (2) & (3) & (4) & (5) & (6) \\
\hline & REN firms & REN firms & REN firms & FF firms & FF firms & FF firms \\
\hline $\mathrm{CF}_{t-1}$ & $\begin{array}{l}0.936 * \\
(0.505)\end{array}$ & $\begin{array}{l}0.983 * \\
(0.544)\end{array}$ & $\begin{array}{l}1.102 * * \\
(0.542)\end{array}$ & $\begin{array}{l}0.167 \\
(0.174)\end{array}$ & $\begin{array}{l}0.170 \\
(0.174)\end{array}$ & $\begin{array}{l}0.085 \\
(0.164)\end{array}$ \\
\hline$\Delta$ Cashholdings $_{t-1}$ & $\begin{array}{l}-0.326 \\
(0.232)\end{array}$ & $\begin{array}{l}-0.309 \\
(0.228)\end{array}$ & $\begin{array}{l}-0.448 * * \\
(0.209)\end{array}$ & $\begin{array}{l}0.052 \\
(0.249)\end{array}$ & $\begin{array}{l}0.066 \\
(0.257)\end{array}$ & $\begin{array}{l}-0.001 \\
(0.266)\end{array}$ \\
\hline $\mathrm{Dbt}_{t-1}$ & & & $\begin{array}{l}-0.142 \\
(0.164)\end{array}$ & & & $\begin{array}{l}-0.737 * * \\
(0.286)\end{array}$ \\
\hline Stk $_{t-1}$ & & & $\begin{array}{l}-0.784 \\
(1.198)\end{array}$ & & & $\begin{array}{l}0.053 \\
(0.552)\end{array}$ \\
\hline Sales $_{t-1}$ & $\begin{array}{l}0.059 \\
(0.037)\end{array}$ & $\begin{array}{l}0.044 \\
(0.040)\end{array}$ & $\begin{array}{l}0.051 \\
(0.041)\end{array}$ & $\begin{array}{l}-0.048 \\
(0.047)\end{array}$ & $\begin{array}{l}-0.050 \\
(0.047)\end{array}$ & $\begin{array}{l}-0.056 \\
(0.054)\end{array}$ \\
\hline $\log (\text { Age })_{t}$ & $\begin{array}{l}-0.346 * * * \\
(0.086)\end{array}$ & $\begin{array}{l}-0.353 * * * \\
(0.085)\end{array}$ & $\begin{array}{l}-0.315 * * * \\
(0.089)\end{array}$ & $\begin{array}{l}-0.163 * * * \\
(0.053)\end{array}$ & $\begin{array}{l}-0.165 * * * \\
(0.053)\end{array}$ & $\begin{array}{l}-0.158 * * * \\
(0.053)\end{array}$ \\
\hline $\log (\text { Employees })_{t}$ & $\begin{array}{l}0.124 * * * \\
(0.030)\end{array}$ & $\begin{array}{l}0.097 * * * \\
(0.032)\end{array}$ & $\begin{array}{l}0.107 * * * \\
(0.035)\end{array}$ & $\begin{array}{l}0.080 * * * \\
(0.021)\end{array}$ & $\begin{array}{l}0.071 * * * \\
(0.021)\end{array}$ & $\begin{array}{l}0.079 * * * \\
(0.022)\end{array}$ \\
\hline $\log (\operatorname{REN~STOCKP})_{t-1}$ & $\begin{array}{l}0.662 * * * \\
(0.169)\end{array}$ & $\begin{array}{l}0.609 * * * \\
(0.159)\end{array}$ & $\begin{array}{l}0.649 * * * \\
(0.157)\end{array}$ & & & \\
\hline $\log (\text { FF STOCKP })_{t-1}$ & & & & $\begin{array}{l}0.892 * * * \\
(0.071)\end{array}$ & $\begin{array}{l}0.878 * * * \\
(0.073)\end{array}$ & $\begin{array}{l}0.893 * * * \\
(0.073)\end{array}$ \\
\hline $\log (\mathrm{FF} \text { prices })_{t-1}$ & & $\begin{array}{l}-1.294 \\
(0.921)\end{array}$ & $\begin{array}{l}-1.148 \\
(0.985)\end{array}$ & & $\begin{array}{l}-1.393 * * \\
(0.618)\end{array}$ & $\begin{array}{l}-1.438 * * \\
(0.638)\end{array}$ \\
\hline $\log (\text { REN market size })_{t-1}$ & & $\begin{array}{l}0.278 * \\
(0.151)\end{array}$ & $\begin{array}{l}0.292 * \\
(0.157)\end{array}$ & & $\begin{array}{l}-0.090 \\
(0.269)\end{array}$ & $\begin{array}{l}0.031 \\
(0.286)\end{array}$ \\
\hline $\log (\text { FF market size })_{t-1}$ & & $\begin{array}{l}-0.252 \\
(0.273)\end{array}$ & $\begin{array}{l}-0.222 \\
(0.287)\end{array}$ & & $\begin{array}{l}-0.201 \\
(0.376)\end{array}$ & $\begin{array}{l}-0.342 \\
(0.367)\end{array}$ \\
\hline Presample & $\begin{array}{l}0.056 \\
(0.048)\end{array}$ & $\begin{array}{l}-0.008 \\
(0.060)\end{array}$ & $\begin{array}{l}-0.008 \\
(0.063)\end{array}$ & $\begin{array}{l}-0.216 * * * \\
(0.050)\end{array}$ & $\begin{array}{l}-0.253 * * * \\
(0.071)\end{array}$ & $\begin{array}{l}-0.237 * * * \\
(0.071)\end{array}$ \\
\hline Constant & $\begin{array}{l}-2.902 * * \\
(1.167)\end{array}$ & $\begin{array}{l}-0.297 \\
(1.938)\end{array}$ & $\begin{array}{l}-0.852 \\
(2.036)\end{array}$ & $\begin{array}{l}-1.693 * * * \\
(0.412)\end{array}$ & $\begin{array}{l}1.307 \\
(1.403)\end{array}$ & $\begin{array}{l}1.368 \\
(1.456)\end{array}$ \\
\hline Observations & 2,326 & 2,136 & 1,995 & 5,086 & 5,063 & 4,811 \\
\hline Log Likelihood & -1170 & -1095 & -1003 & -2585 & -2577 & -2448 \\
\hline Year FE & Yes & Yes & Yes & Yes & Yes & Yes \\
\hline Number of firms & 443 & 417 & 390 & 844 & 843 & 813 \\
\hline
\end{tabular}

$* p \leq 0.1, * * p \leq 0.05, * * * p \leq 0.01$. The dependent variable in every column is the number of patents in technology $z$ per firm $i$ and year $t$ for the subsamples of REN firms and FF firms, respectively. Robust standard errors are clustered at the firm level. All specifications include year fixed effects. Fossil fuel price and market size variables are constructed by using firm-specific weights reflecting the firms' patent portfolio and designation countries as in Noailly and Smeets (2015)

are more vulnerable to financing constraints than FF firms. The significant difference in innovation-cash flows sensitivity between REN and FF firms still holds if we restrict the samples to consider only large and mature firms. This suggests that the finding that REN firms are more financially constrained than FF firms is for the most part likely to be a manifestation of the environmental market failure (reliance on uncertain public support) 
Table 4 Robustness results

\begin{tabular}{|c|c|c|c|}
\hline & (1) & (2) & (3) \\
\hline & Mature & Large & Poisson \\
\hline \multirow[t]{2}{*}{$\mathrm{CF}_{t-1}$} & -0.285 & -0.342 & 0.016 \\
\hline & $(0.453)$ & $(0.406)$ & $(0.165)$ \\
\hline \multirow[t]{2}{*}{$\mathrm{CF}_{t-1} \times \mathrm{REN}$ firms } & $1.583 * * *$ & $1.509 * * *$ & 0.299 \\
\hline & $(0.508)$ & $(0.476)$ & $(0.201)$ \\
\hline \multirow[t]{2}{*}{$\Delta$ Cashholdings $_{t-1}$} & 0.106 & -0.801 & 0.038 \\
\hline & $(0.473)$ & $(0.529)$ & $(0.211)$ \\
\hline \multirow[t]{2}{*}{$\Delta$ Cashholdings $_{t-1} \times \mathrm{REN}$ firms } & 0.891 & 0.311 & -0.184 \\
\hline & $(1.158)$ & $(0.534)$ & $(0.224)$ \\
\hline \multirow[t]{2}{*}{ RENfirms } & $0.291 *$ & $0.388 * *$ & $0.650 * * *$ \\
\hline & $(0.164)$ & $(0.176)$ & $(0.177)$ \\
\hline \multirow[t]{2}{*}{$\mathrm{Dbt}_{t-1}$} & -0.485 & $-0.461 *$ & -0.227 \\
\hline & $(0.383)$ & $(0.247)$ & $(0.193)$ \\
\hline \multirow[t]{2}{*}{ Stk $_{t-1}$} & $-2.654 *$ & 0.639 & -0.219 \\
\hline & $(1.585)$ & $(0.475)$ & $(0.608)$ \\
\hline \multirow{2}{*}{$\log (\text { Age })_{t}$} & -0.143 & $-0.225 * * *$ & $-0.218 * * *$ \\
\hline & $(0.126)$ & $(0.057)$ & $(0.064)$ \\
\hline \multirow[t]{2}{*}{$\log (\text { Employees })_{t}$} & 0.042 & 0.053 & $0.080 * * *$ \\
\hline & $(0.026)$ & $(0.036)$ & $(0.020)$ \\
\hline \multirow[t]{2}{*}{ Sales $_{t-1}$} & -0.035 & 0.048 & 0.042 \\
\hline & $(0.065)$ & $(0.056)$ & $(0.037)$ \\
\hline \multirow[t]{2}{*}{$\log (\mathrm{STOCKP})_{t-1}$} & $0.888 * * *$ & $0.961 * * *$ & $0.991 * * *$ \\
\hline & $(0.089)$ & $(0.065)$ & $(0.054)$ \\
\hline \multirow{2}{*}{$\log (\text { FF prices })_{t-1}$} & $-2.153 * * *$ & $-1.709 * *$ & $-1.230 * *$ \\
\hline & $(0.618)$ & $(0.751)$ & $(0.601)$ \\
\hline \multirow[t]{2}{*}{$\log (\operatorname{REN} \text { market size })_{t-1}$} & $0.307 * *$ & $0.329 *$ & $0.463 * * *$ \\
\hline & $(0.153)$ & $(0.183)$ & $(0.162)$ \\
\hline \multirow[t]{2}{*}{$\log (\text { FF market size })_{t-1}$} & -0.019 & 0.156 & -0.070 \\
\hline & $(0.283)$ & $(0.272)$ & $(0.223)$ \\
\hline \multirow[t]{2}{*}{ Presample } & -0.122 & $-0.097 *$ & $-0.144 *$ \\
\hline & $(0.171)$ & $(0.058)$ & $(0.074)$ \\
\hline \multirow[t]{2}{*}{ Constant } & 1.458 & -0.076 & -0.816 \\
\hline & $(1.333)$ & $(1.490)$ & $(1.136)$ \\
\hline \multicolumn{4}{|c|}{ Total interaction terms (Delta Method) } \\
\hline \multirow[t]{2}{*}{$\mathrm{CF}_{\mathrm{t}-1} * \mathrm{REN}$ firms } & $0.365 * * *$ & $0.483 * * *$ & $0.089 * *$ \\
\hline & $(0.102)$ & $(0.13)$ & $(0.039)$ \\
\hline \multirow[t]{2}{*}{ CashHoldings $_{\mathrm{t}-1} *$ REN firms } & 0.216 & 0.008 & -0.046 \\
\hline & $(0.262)$ & $(0.127)$ & $(0.041)$ \\
\hline Observations & 3,375 & 3,643 & 6,806 \\
\hline Log Likelihood & -1677 & -2175 & -3789 \\
\hline Number of firms & 555 & 632 & 1203 \\
\hline
\end{tabular}

$* p<0.1, * * p<0.05, * * * p<0.01$. The dependent variable in every column is the number of patents per firm $i$ and year $t$ for the pooled sample of specialized firms (REN and FF firms). Robust standard errors are clustered at the firm level. All specifications include year fixed effects. Fossil fuel price and market size variables are constructed by using firm-specific weights reflecting the firms' patent portfolio and designation countries as in Noailly and Smeets (2015) 
and differences in technological risks, rather than explained by the lower maturity of the industry.

Our results shed light on how distinct risk-profiles between clean and dirty energy technologies may affect the financing of energy innovation and thereby drive the direction of technological change, as financiers will tend to support lower-risk technologies that are easier to finance. This has important implications for future energy transition policies as more innovation is still needed in advanced clean energy technologies, such as decentralized renewable energy, advanced biofuels or unproven solar technologies and as the pace of the energy transition will necessarily need to accelerate to meet the climate neutrality goal by 2050 . Our analysis emphasizes that policies should not only aim at mobilizing finance to fill the investment gap for clean energy targets but also consider gradually decreasing, discouraging or even banning the financing of fossil-fuel innovation. In this respect, the announcement by the European Investment Bank to stop funding oil, gas and coal projects at the end of 2021 is a move in the good direction. Under the new policy, energy projects applying for the European Investment Bank funding will need to show that they can produce one kilowatt hour of energy while emitting less than 250 grams of carbon dioxyde. In a similar way, it could be useful to reevaluate the portfolio of policy instruments for energy innovation, ranging from public grants and contracts, loans or guarantees, public-private equity partnerships, innovation prizes and tax credits (Olmos et al. 2012) to gradually remove financial support for fossil-fuel R\&D. An additional implication is that financial institutions should be able to better assess and scrutinize clean energy projects. In this context, the process of developing a standardized Green Taxonomy to support the European Green New deal is a promising initiative.

As a first attempt to investigate the role of financing constraints for renewable versus fossilfuel innovation, our analysis presents several limitations due to our small sample of firms. Future work could take advantage of larger datasets allowing more refined econometric techniques to provide a more thorough empirical investigation of how firms' financing sources - cash, debt and equity - affect firms' R\&D investments in energy technologies. Several questions are left for future research, such as for instance the role of the financial crisis, potential variation across specific REN technologies (e.g solar vs. wind or biomass), the role of large incumbent FF firms increasingly diversifying their patent portfolio to innovate also in REN technologies, or the importance of policy risks versus technological risks in explaining financing constraints.

\section{Appendix}

\section{Delta Method for Computing Interaction Terms}

Our baseline equation is as follows:

$$
\begin{aligned}
E\left(\text { PAT }_{z, i t} / X_{z, i t}, v_{i}, \omega t\right)= & \exp \left(\beta_{1} \text { CashFlows }_{z, i t-1}+\beta_{2} \Delta \text { CashHold }_{z, i t-1}\right. \\
& +\beta_{11} \text { CashFlows }_{z, i t-1} * \text { RENfirms }_{i} \\
& +\beta_{22} \Delta \text { CashHold }_{z, i t-1} * \text { RENfirms }_{i} \\
& +\beta_{F} \text { RENfirms }_{i}+\beta_{3} \text { EXT }_{z, i t-1} \\
& \left.+\beta_{4} \text { STOCKP }_{z, i t}+\beta_{5} X_{z, i t}+v_{i}+\omega_{t}+\epsilon_{z, i t}\right)
\end{aligned}
$$

According to the Delta method (Ai and Norton 2003), the total interaction term on (CashFlows $_{z, i t-1} *$ RENfirms) is computed as follows: 


$$
\begin{aligned}
\frac{\delta^{2} E\left(\text { PAT }_{z, i t} / X_{z, i t}, v_{i}, \omega_{t}\right)}{\delta \text { CashFlows }_{z, i t-1} \text { SRENfirms }_{i}} & =\left[\left(\beta_{1}+\beta_{11} \text { CashFlows }_{z, i t-1} * \text { RENfirms }_{i}\right)\right. \\
& \left.*\left(\beta_{F}+\beta_{11} \text { RENfirms }_{i}\right)+\beta_{11}\right] E\left(P A T_{z, i t} / X_{z, i t}, v_{i}, \omega_{t}\right)
\end{aligned}
$$

\section{First-stage Control Function Approach}

\section{Variables Definitions}

For a detailed description of the variable construction we refer to Noailly and Smeets (2015).

The fossil-fuel price faced by firm $i$ at time $t$ is computed as:

$$
\begin{aligned}
& p_{i t}=\sum_{c} w_{i c} \times p_{c t} \\
& \text { s.t. } p_{c t}=\sum_{f=\text { oil,coal,gas }} \frac{M_{f c}}{M_{F F c}} \times p_{f c t}
\end{aligned}
$$

where $p_{c t}$ is the sum of $(\log )$ fossil-fuel prices $p_{f c t}$ (oil, coal and gas) in country $c$ at time $t$, weighted by the respective average market shares of each fossil fuel type in that country. This price is then multiplied by the weight $w_{i c}=\frac{P_{i t} \times M_{F F i c}}{\sum P_{i t} M_{F F i c}}$, where $P_{i c}$ is the total number of patents filed by firm $i$ in designation country $c$ and $M_{F F c}$ is the country's FF average market size. $^{23}$

As with prices in (5), we construct fixed firm-specific designation country weights $w_{i k}$ to compute firm-level FF and REN market sizes. However, we now also introduce fixed firmspecific technology weights $w_{i s}$ to account for the fact that e.g. a firm innovating mainly in solar power will be mostly concerned with the market size for solar energy. Hence we compute:

$$
M_{i t}=\sum_{c} \sum_{s} w_{i s c} M_{s c t}
$$

with $w_{i s c}=\frac{P_{i s c}}{\sum_{s} \sum_{c} P_{i s c}}$, where $P_{i s c}$ is the number of patents of firm $i$ in technology $s$ in country $c$ and $M_{s c t}$ is the market size of technology $s$ in country $c$.

To compute FF technology weights $w_{i s c}$ we use a correspondence between the FF technological areas and oil, gas or coal fuels as provided in Lanzi et al. (2011). For instance, technologies in the field of production of fuel gases by carburetting air are assigned to the market size of electricity output from coal. For those FF innovations without such a correspondence, we assign the weighted average market size of all three fuel sources. Finally, we also compute firm-specific REN market sizes for firms innovating only in FF technologies. To do so, we assign country-level market size averaged across all REN technologies,

\footnotetext{
23 All our weights are fixed, i.e. we compute total patent counts $P_{i c}$ and average market sizes $M_{F F c}$ over the whole sample period. If changes in FF prices affect the country mix of the patent portfolio or the size of the FF market, not fixing the weights might feed back into the prices, causing potential endogeneity.
} 
Table 5 First-stage - Control function estimations

\begin{tabular}{|c|c|c|c|c|}
\hline Dependent variable & $\begin{array}{l}\mathrm{CF}_{t-1} \\
(1)\end{array}$ & $\begin{array}{l}\mathrm{CF}_{t-1} \\
(2)\end{array}$ & $\begin{array}{l}\Delta \text { Cashholdings }_{t-1} \\
\text { (3) }\end{array}$ & $\begin{array}{l}\Delta \text { Cashholdings }_{t-1} \\
\text { (4) }\end{array}$ \\
\hline $\mathrm{CF}_{t-3, t-4}$ & $\begin{array}{l}0.534 * * * \\
(0.113)\end{array}$ & & & \\
\hline $\mathrm{CF}_{t-2, t-3}$ & & $\begin{array}{l}0.818 * * * \\
(0.045)\end{array}$ & & \\
\hline$\Delta$ Cashholdings $_{t-3, t-4}$ & & & $\begin{array}{l}-0.026 \\
(0.056)\end{array}$ & \\
\hline$\Delta$ Cashholdings $_{t-2, t-3}$ & & & & $\begin{array}{l}-0.093 \\
(0.081)\end{array}$ \\
\hline $\mathrm{CF}_{t-1}$ & & & $\begin{array}{l}0.204 * \\
(0.112)\end{array}$ & $\begin{array}{l}0.200 * \\
(0.112)\end{array}$ \\
\hline$\Delta$ Cashholdings $_{t-1}$ & $\begin{array}{l}0.202 * * * \\
(0.019)\end{array}$ & $\begin{array}{l}0.159 * * * \\
(0.023)\end{array}$ & & \\
\hline $\mathrm{Dbt}_{t-1}$ & $\begin{array}{l}-0.005 \\
(0.013)\end{array}$ & $\begin{array}{l}-0.006 \\
(0.011)\end{array}$ & $\begin{array}{l}0.131 * * * \\
(0.030)\end{array}$ & $\begin{array}{l}0.192 * * * \\
(0.069)\end{array}$ \\
\hline Stk $_{t-1}$ & $\begin{array}{l}-0.128 * * \\
(0.064)\end{array}$ & $\begin{array}{l}-0.010 \\
(0.024)\end{array}$ & $\begin{array}{l}0.929 * \\
(0.545)\end{array}$ & $\begin{array}{l}0.944 * \\
(0.535)\end{array}$ \\
\hline $\log (\text { Age })_{t}$ & $\begin{array}{l}-0.000 \\
(0.002)\end{array}$ & $\begin{array}{l}-0.002 \\
(0.002)\end{array}$ & $\begin{array}{l}-0.001 \\
(0.003)\end{array}$ & $\begin{array}{l}0.000 \\
(0.003)\end{array}$ \\
\hline $\log (\text { Employees })_{t}$ & $\begin{array}{l}0.004 * * * \\
(0.001)\end{array}$ & $\begin{array}{l}0.003 * * * \\
(0.001)\end{array}$ & $\begin{array}{l}0.001 \\
(0.003)\end{array}$ & $\begin{array}{l}0.002 \\
(0.003)\end{array}$ \\
\hline Sales $_{t-1}$ & $\begin{array}{l}0.019 * * * \\
(0.004)\end{array}$ & $\begin{array}{l}0.017 * * * \\
(0.003)\end{array}$ & $\begin{array}{l}0.071 * \\
(0.043)\end{array}$ & $\begin{array}{l}0.085 * \\
(0.051)\end{array}$ \\
\hline $\log (\text { STOCKP })_{t-1}$ & $\begin{array}{l}-0.005 * \\
(0.003)\end{array}$ & $\begin{array}{l}-0.003 \\
(0.003)\end{array}$ & $\begin{array}{l}0.008 * * \\
(0.004)\end{array}$ & $\begin{array}{l}0.010 * * \\
(0.004)\end{array}$ \\
\hline $\log (\text { FF prices })_{t-1}$ & $\begin{array}{l}-0.001 \\
(0.026)\end{array}$ & $\begin{array}{l}0.013 \\
(0.023)\end{array}$ & $\begin{array}{l}0.114 \\
(0.091)\end{array}$ & $\begin{array}{l}0.135 \\
(0.093)\end{array}$ \\
\hline $\log (\text { REN market size })_{t-1}$ & $\begin{array}{l}-0.009 * * * \\
(0.003)\end{array}$ & $\begin{array}{l}-0.004 \\
(0.003)\end{array}$ & $\begin{array}{l}0.005 \\
(0.008)\end{array}$ & $\begin{array}{l}0.008 \\
(0.008)\end{array}$ \\
\hline $\log (\mathrm{FF} \text { market size })_{t-1}$ & $\begin{array}{l}0.035 * * \\
(0.015)\end{array}$ & $\begin{array}{l}0.026 * * \\
(0.013)\end{array}$ & $\begin{array}{l}-0.025 \\
(0.022)\end{array}$ & $\begin{array}{l}-0.021 \\
(0.018)\end{array}$ \\
\hline presample & $\begin{array}{l}0.001 \\
(0.001)\end{array}$ & $\begin{array}{l}0.001 \\
(0.001)\end{array}$ & $\begin{array}{l}0.002 \\
(0.002)\end{array}$ & $\begin{array}{l}0.003 \\
(0.002)\end{array}$ \\
\hline Constant & $\begin{array}{l}-0.040 \\
(0.042)\end{array}$ & $\begin{array}{l}-0.074 * * \\
(0.035)\end{array}$ & & $\begin{array}{l}-0.074 * * \\
(0.035)\end{array}$ \\
\hline Observations & 5,866 & 6,726 & 5,966 & 4,989 \\
\hline R-squared & 0.245 & 0.326 & 0.291 & 0.320 \\
\hline
\end{tabular}

$p \leq 0.1, * * p \leq 0.05, * * * p \leq 0.01$. Robust standard errors are clustered at the firm level. Fossil fuel price and market size variables are constructed by using firm-specific weights reflecting the firms' patent portfolio and designation countries as in Noailly and Smeets (2015)

also using the relevant country-weights $\left(w_{i k}\right)$. We proceed in a similar manner to assign FF market sizes to firms that innovate only in REN technologies. 
Table 6 Construction and sources of variables

\begin{tabular}{|c|c|c|c|}
\hline Variable & Construction & Data source & Time-period \\
\hline Renewable (REN) patents & $\begin{array}{l}\text { Count of patents in wind, solar, } \\
\text { hydro, marine, biomass, } \\
\text { geothermal, and waste energy } \\
\text { technologies }\end{array}$ & Orbis-EPO (PATSTAT) & 1995-2009 \\
\hline Fossil fuel (FF) patents & $\begin{array}{l}\text { Count of patents in fuel } \\
\text { gases by carbureting air, } \\
\text { steam engine plants, gas } \\
\text { turbine plants, hot-gas or } \\
\text { combustion-product positive } \\
\text { displacement engine, steam } \\
\text { generation, combustion appa- } \\
\text { ratus, furnaces, and improved } \\
\text { compressed-ignition engines } \\
\text { technologies }\end{array}$ & Orbis-EPO (PATSTAT) & 1995-2009 \\
\hline Stock issues & $\frac{\text { Capital }_{t}-\text { Capital }_{t-1}}{\text { TotalAssets }_{t-1}}$ & Orbis & 1995-2009 \\
\hline Long-term debt & $\frac{\text { LongTermDebt }_{t}-\text { LongTermDebt }_{t-1}}{\text { TotalAsset }_{t-1}}$ & Orbis & 1995-2009 \\
\hline Cash flows & $\frac{\text { CashFlow }_{t}}{\text { TotalAsset }_{t-1}}$ & Orbis & 1995-2009 \\
\hline Sales & $\frac{\text { Sales }_{t}}{\text { TotalAssets }_{t-1}}$ & Orbis & 1995-2009 \\
\hline$\Delta$ CashHolding & $\frac{\text { CashEquivalents }_{t}-\text { CashEquivalent }_{t-1}}{\text { TotalAsset }_{t-1}}$ & Orbis & 1995-2009 \\
\hline Log employees & $\log ($ Employees+1) & Orbis & 1995-2009 \\
\hline Log age & $\begin{array}{l}\text { Log(Year-Date of incorpora- } \\
\text { tion+ } 1)\end{array}$ & Orbis & \\
\hline Fossil fuel (FF) price & $\begin{array}{l}\text { see below - Noailly and Smeets } \\
\text { (2015) }\end{array}$ & IEA, PATSTAT, INPADOC & 1995-2009 \\
\hline REN and FF market size & $\begin{array}{l}\text { see below - Noailly and Smeets } \\
\text { (2015) }\end{array}$ & IEA, PATSTAT, INPADOC & 1995-2009 \\
\hline REN and FF knowledge stock & $(1-\delta) S T O C K P_{z, i t-1}+P_{z, i t}$ & Orbis, PATSTAT & 1995-2009 \\
\hline
\end{tabular}

Table 7 Summary Statistics for 'mixed firms' patenting in both REN and FF (N=90 firms)

\begin{tabular}{lllllll}
\hline \multicolumn{7}{l}{ Mixed firms } \\
\cline { 2 - 6 } & Mean & SD & 50th perc. & 75th perc. & Min & Max \\
\hline CF $_{t-1}$ & 0.110 & 0.219 & 0.091 & 0.140 & -0.565 & 4.529 \\
CashHolding $_{t-1}$ & 0.120 & 0.379 & 0.047 & 0.129 & 0.000 & 6.172 \\
Dbt $_{t-1}$ & 0.061 & 0.0802 & 0.000 & 0.024 & -0.794 & 17.84 \\
Stk $_{t-1}$ & 0.018 & 0.168 & 0.001 & 0.005 & 0.000 & 3.727 \\
Sales $_{t}$ & 1.345 & 3.444 & 1.03 & 1.48 & 0.002 & 76.72 \\
Total Assets $_{t}$ & 25,874 & 51,789 & 4,279 & 26,715 & 18.14 & 379,679 \\
Age $_{t}$ & 51 & 38 & 43 & 78 & 2 & 149 \\
Employees $_{t}$ & 10,873 & 24,874 & 1,356 & 9,457 & 0 & 196,880 \\
REN patents $_{t}$ & 0.297 & 0.791 & 0 & 0 & 0 & 7 \\
FF patents $_{t}$ & 1.513 & 5.479 & 0 & 1 & 0 & 57 \\
All patents $_{t}$ & 44.32 & 136.1 & 8 & 38.5 & 0 & 1,518 \\
\hline
\end{tabular}

Average over firm-year observations, 1995-2009: Number of firm-year observations: Mixed firms N=528 (90 firms) 
Knowledge stocks are computed using the perpetual inventory method as STOCKP $P_{z, i t}=(1-\delta) S T O C K P_{z, t-1}+P_{z, i t}$, where $\delta$ is the depreciation rate and $P_{t}$ is the total number of patents filed by firm $i$ at time $t$.

\section{Methodology and Data Cleaning of the Orbis Dataset}

To construct the firm-level financial variables, we follow the following steps for data cleaning as in Kalemli-Ozcan et al. (2015).

1. We check the consistency of accounting identities (ratio should not be larger than 10)

- Fixedassets-tangiblefixedassets-intangiblefixedassets-otherfixedassets)/fixedassets

- Totalassets - fixedassets-currentassets)/totalassets

- Noncurrentliabilities - longtermdebt - othernoncurrentliabilities)/noncurrentliabilities

- Currentliabilities - loans - creditors - othercurrentliabilities)/currentliabilities

- Totalsharehfundsliab-loans)/totalsharehfundsliab

- Totalsharehfundsliab-longtermdebt)/totalsharehfundsliab

2. We drop the entire company (all years) if total assets is negative in any year.

3. We drop the entire company (all years) if sales is negative in any year.

4. We drop the entire company (all years) if tangible fixed assets (such as buildings, machinery, etc) is negative in any year

5. For some firms, there are some inconsistencies in the units of financial variables (as noted by Kalemli-Ozcan, 2015 on p.29). The moment of switch in units coincides with an "unreasonable" move of total assets, often clustered around the year 2000. To solve for this, we focus on firms with total assets above 1 million USD.

6. We also winsorize all financial variables by trimming the data at $1 \%$.

Open Access This article is licensed under a Creative Commons Attribution 4.0 International License, which permits use, sharing, adaptation, distribution and reproduction in any medium or format, as long as you give appropriate credit to the original author(s) and the source, provide a link to the Creative Commons licence, and indicate if changes were made. The images or other third party material in this article are included in the article's Creative Commons licence, unless indicated otherwise in a credit line to the material. If material is not included in the article's Creative Commons licence and your intended use is not permitted by statutory regulation or exceeds the permitted use, you will need to obtain permission directly from the copyright holder. To view a copy of this licence, visit http://creativecommons.org/licenses/by/4.0/.

\section{References}

Abraham J (2011) Evolving sociological analyses of pharmaceuticalisation: a response to Williams, Martin and Gabe. Sociol Health Illness 33(5):726-728

Acemoglu D, Aghion P, Bursztyn L, Hemous D (2012) The environment and directed technical change. Am Econ Rev 102(1):131-166

Aghion P, Dechezlepretre A, Hemous D, Martin R, van Reenen J (2016) Carbon taxes, path dependency and directed technical change: evidence from the auto industry. J Political Econ 124(1):1-51

Ai C, Norton EC (2003) Interaction terms in logit and probit models. Econ Lett 80(1):123-129

Aydogan A (2003) How sensitive is investment to cash flow when financing is frictionless? J Financ 58(2):707-722 
Blundell R, Griffith R, Windmeijer F (2002) Individual effects and dynamics in count data models. J Econ 108(1):113-131

Brown JR, Martinsson G, Petersen BC (2012) Do financing constraints matter for R\&D? Euro Econ Rev 56:1512-1529

Brown JR, Petersen BC (2009) Why has the investment-cash flow sensitivity declined so sharply? Rising R\&D and equity market developments. J Bank Financ 33(5):971-984

Brown JR, Petersen BC (2011) Cash holdings and R\&D smoothing. J Corp Financ 17(3):694-709

Cameron AC, Trivedi P (2013) Regression Analysis of Count Data, 2nd edn. Cambridge University Press, Cambridge

Conti A, Thursby J, Thursby M (2013) Patents as signals for startup financing. J Indus Econ 61(3):592-622

Criscuolo C, Menon C (2015) Environmental policies and risk finance in the green sector: cross-country evidence. Energy Policy 83:38-56

Donovan CW (2015) Renewable energy finance: powering the future. World Scientific, Singapore

Erickson T, Whited TM (2000) Measurement error and the relationship between investment and $q$. J Political Econ 108(5):1027-1057

European Commission (2020) Proposal for a regulation of the European Parliament and of the Council establishing the framework for achieving climate neutrality and amending regulation (EU) 2018/1999 (European Climate Law). Brussels

Frankfurt School-UNEP Centre/BNEF (2017) 'Global trends in renewable energy investment 2017'. Report Frankfurt School-UNEP Centre/Bloomberg New Energy Finance

Gaddy B, Sivaram V, O'Sullivan F (2016) 'Venture Capital and Cleantech: The Wrong Model for Clean Energy Innovation'. Report MIT Energy Initiative

Ghosh S, Nanda R (2010) 'Venture capital investment in the clean energy sector'. Working Paper No. 11-020, Harvard Business School Entrepreneurial Management

Griliches Z (1990) Patent statistics as economic indicators: a survey. J Econ Lit 28(4):1661-1707

Hall BH, Lerner J (2010) Handbook of the Economics of Innovation. Vol. 1. North Holland. Chapter The Financing of R\&D and Innovation, pp. 609-639

Hausman JA, Hall BH, Griliches Z (1984) Econometric models for count data with an application to the patents-R\&D relationship. NBER Working Paper 17.

Himmelberg CP, Petersen BC (1994) R\&D and internal finance: a panel study of small firms in high-tech industries. Rev Econ Stat 76(1):38-51

Howell ST (2017) Financing innovation: evidence from R\&D grants. Am Econ Rev 107(4):1136-64

IEA (2015) World Energy Outlook. IEA, Paris, France

IEA (2017) Tracking clean energy progress 2017. IEA, Paris

Johnstone N, Hascic I, Popp D (2010) Renewable energy policies and technological innovation: evidence based on patent counts. Environ Resour Econ 45(1):133-155

Kalemli-Ozcan S, Sorensen B, Villegas-Sanchez C, Volosovych V, Yesiltas S (2015) How to construct nationally representative firm level data from the ORBIS global database. NBER Working Paper 21558

Lanzi E, Verdolini E, Hascic I (2011) Efficiency improving fossil fuel technologies for eletricity generation: data selection and trends. Energy Policy 39(11):7000-7014

Loof H, Nabavi P (2016) Innovation and credit constraints: evidence from Swedish exporting firms. Econ Innov New Technol 25(3):269-282

McCollum DL, Zhou W, Bertram C, De Boer HS, Bosetti V, Busch S, Després J, Drouet L, Emmerling J, Fay M et al (2018) Energy investment needs for fulfilling the Paris agreement and achieving the sustainable development goals. Nature Energy 3(7):589-599

Mulkay B, Hall BH, Mairesse J (2001) Firm level investment and R\&D in France and the United States: a comparison. In: Deutsche B (ed) Investing today for the world of tomorrow. Springer, Berlin, Heidelberg, pp 229-273

Nanda R, Younge K, Fleming L (2015) Innovation and entrepreneurship in renewable energy. In: Jaffe AB, Jones BF (eds) The changing frontier: rethinking science and innovation policy, University of Chicago Press, pp 199-232

Nelson D, Shrimali G (2014) Finance mechanisms for lowering the cost of renewable energy in rapidly developing countries. Report Climate Policy Initiative

Noailly J, Smeets R (2015) Directing technical change from fossil-fuel to renewable energy innovation: an application using firm-level data. J Environ Econ Manag 72(C):15-37

Olmos L, Ruester S, Liong S-J (2012) On the selection of financing instruments to push the development of new technologies: application to clean energy technologies. Energy Policy 43:252-266

Papies D, Ebbes P, Van Heerde HJ (2017) Addressing endogeneity in marketing models. In: Leeflang P, Wieringa J, Tammo HA, Bijmolt K (eds) Advanced methods for modeling markets international series in quantitative marketing. Springer International Publishing, pp 581-627 
Polzin F, Sanders M (2020) How to finance the transition to low-carbon energy in Europe? Energy Policy $147: 111-863$

Popp D (2002) Induced innovation and energy prices. Am Econ Rev 92(1):160-180

Wooldridge JM (2015) Control function methods in applied econometrics. J Human Resour 50(2):420-445

Publisher's Note Springer Nature remains neutral with regard to jurisdictional claims in published maps and institutional affiliations. 